\title{
Investment Constraints in Urban Regeneration: Property Developers and Local Authorities Perspective
}

\author{
Nurulanis Ahmad @ Mohamed ${ }^{1, a}$, Zarita Ahmad Baharum², Asma Senawi ${ }^{3}$ and Nor Aini Salleh ${ }^{4}$ \\ ${ }^{1, a}$ Faculty of Architecture, Planning and Surveying, Universiti Teknologi MARA, Seri Iskandar Campus, Seri Iskandar, 32610, Perak, Malaysia \\ ${ }^{2}$ Faculty of Architecture, Planning and Surveying, Universiti Teknologi MARA, Shah Alam Campus, Shah Alam, 40450, Selangor, Malaysia \\ ${ }^{3}$ Faculty of Architecture, Planning and Surveying, Universiti Teknologi MARA, Seri Iskandar Campus, Seri Iskandar, 32610, Perak, Malaysia \\ ${ }^{4}$ Faculty of Architecture, Planning and Surveying, Universiti Teknologi MARA, Seri Iskandar Campus, Seri Iskandar, 32610, Perak, Malaysia
}

\begin{abstract}
Urban decay is a phenomenon created due to the expansion of urban population, the restructuring of industrial, social composition as well as the deterioration of urban areas. Consequently this will increase issues of crime, mass unemployment, low quality in urban services, social problems etc. Thus urban regeneration is a tool used to overcome all these issues in order to create quality of urban living, diversify and vibrant cities. However, the involvement of investment in urban regeneration is still infancy in Malaysia as compared to other countries such as Australia, UK, Hong Kong, and etc. This is due to the perception of investors towards the profit generation and the risk involve. The objective of this paper is to determine the constraints involved in urban regeneration investment from the perspectives of the property developer companies and the local authorities. The method used is an exploratory with primary data collection through a questionnaire survey. The findings revealed that the main constraints is in regards of the land issues as well as high cost of investment, however, the benefits gain should also be considered as this create a livable urban living.
\end{abstract}

\section{Introduction}

Urban regeneration is a strategic solution to the challenges provided by the growing urbanization itself towards revitalize a city in a sustainable lifestyle concept and resilience (Robert and Skyes, 2000[24]; IOER, 2005[17]).The evolution of urban regeneration arises in the 1990s due to the rapid change of industrial structure in many cities in the UK and Europe in the mid 1970s. Regeneration projects carry many benefits which include offering an attractive vibrant property market through innovative and smart growth development concept (Adair et al, .2003[3]); able to attract business and create job opportunities (Goksin and Muderrisoglu, 2005[15]); improve quality of the environment (Couch, 1990[9]); reinforce civic pride and a sense of place (Goksin and Muderrisoglu, 2005[15]); and concern on long term approach and avoid future problems (Robert and Skyes, 2000 [24]). It has been recognized as one of a tool to achieve sustainable and resilience, urban living and environment.

The implementation and investment of urban regeneration worldwide has increase over the years, for example in the UK, the total investment in urban regeneration project has increased from $£ 8.3$ billion in 2009 to $£ 11.6$ billion at end of 2012 (Planning in Association with Regeneration and Renewal, 2013[25]); Africa from RM 55 million in 2013 to RM125 million in 2015 (Cox, Viruly, Bertoldi, 2015[10]); and the

\footnotetext{
${ }^{\mathrm{a}}$ Corresponding author: nurul513@perak.uitm.edu.my
}

Oklahoma City, USA significant growth from $\$ 942$ million in 2003 and $\$ 1.2$ billion in 2005 (Warner and Long, 2009[29]).

The success of urban regeneration has proved to create a livable urban living, even though it often involves high investment cost. However, urban regeneration in Malaysia is still infancy and involved very little participation from the local government as well as the developer. To date, there are only four cities that involve in urban regeneration project namely Kuala Lumpur, Georgetown, Melaka and Johor Bahru (Nilai Harta, 2015[23]). Although there are many potential projects for urban regeneration, the local authorities and the developers seem to be reluctant to pursue with this investment. Thus, the objective of this paper is to determine the constraints involved in urban regeneration investment from the perspectives of the property developer companies and the local authorities.

\section{Background of the Study}

Urbanization is a global phenomenon to all the large cities worldwide. The driving force behind the rapid growth in urbanization is due to the industrialization and migration. There are cities that cannot sustain urbanization which consequently will face economic and social decline due to the structural change in the local economy. This process whereby the previously function 
cities will fall into disrepair and decrepitude is known as urban decay. Urban decay is a phenomenon created due to the expansion of urban population, the restructuring of industrial, social composition as well as the deterioration of urban areas. As a result, this will increase issues of crime, mass unemployment, low quality in urban services, social problems etc. Thus urban regeneration is a tool used to overcome all these issues in order to create quality of urban living, diversify and vibrant cities.

The rate of urbanization in Malaysia has increase tremendously over the years from less than $50 \%$ in 1990 to more than $70 \%$ in 2010 and expected to rise further $75 \%$ by year 2020 (The Edge, 2014[28]). The growth in the population size in major cities in Malaysia over the years is very astounding and this trend is expected to grow from 30.1 million in 2015 to 38.6 million in 2040 with an increase of 28\% (Malaysia Statistic Department, 2015[19]). The change in the society, restructuring economic and policy review would cause some areas in the cities deteriorate and decline. Therefore, urban regeneration is a solution focusing on specific society needs to revitalize the blighted areas in city centre into a better urban infrastructure and improve the quality of environment towards sustainable lifestyle, intelligence and resilience of the city. It is a key driver of economic, physical and social growth (Eni et al, .2013[12]). The concept of urban regeneration is to tackle the decline of many urban areas through investment and improve infrastructure. Considering the regeneration advantages and in tandem with Malaysia's mission to become a sustainable and strategic country of socio economic development in year 2020, investment towards urban regeneration project is crucial in order to achieve the strategic direction.

The developers and local authorities are not motivated to be involved in urban regeneration projects due to their perception that the investment is costly, risky, lack of information and low profitability. The trends in other countries prove otherwise as urban regeneration is well accepted and implemented as a lucrative investment and development, for examples Langham Place in Hong Kong, London Docklands in UK and False Creek in Canada.

\section{Investment constraints in urban regeneration}

Any investment in whatever nature, industry and circumstances will directly and indirectly faces constraints. The significant differences are the magnitude of the constraints and the approaches use to tackle the constraints. Investment in urban regeneration is no doubt a challenging task and involves a huge capital investment. Constraints in regards to urban regeneration investment can be divided into six categories which include risks, return, governance, costs and property tax, damage neighborhood and social network, and problems with multiple ownerships.

\subsection{Risks}

Risks are often related to profit (Samworth and Lacey, 1998[26]). A research by McNamara (1993[21]) stated that regeneration areas are known to investor as medium of risk and uncertain. Among the risks involved in urban regeneration areas include planning, yield and rent, development costs, contamination and stigma, development period, tenure of finance, and market volatility (Adair, Hutchison, Burgess and Roulac, 2005[4]). Simons (1998[27]) pointed out that the higher development cost and longer duration in development will also affect the risk involved. For instances, the early stage of development such as site assembly, demolition, and clearance often cause a longer duration and affect the finance charges (Adams et al, .1998[5]). Other than that, risk such as tenant needs before lease out, economic condition during construction, shortage of material and labor, market conditions, unforeseen conditions and delay government approval also among risk involve in investment of urban regeneration (Epley, Rabianski and Haney, 2002[13]). A report by ERM Economics (2002[14]) emphasized that the risk will rise more in investment of urban regeneration due to lack of information on return received, misperceived returns, high transaction cost, information costs, risk aversion, low demands, financial constraints, high cost of market survey, land contamination survey and detail feasibility studies. This is supported by Adair et al (1998[2]) where lack of information or transparency will result in uncertainty in regeneration investment.

\subsection{Return}

The perception of poor return and low profitability is another area of constraints in urban regeneration investment. Poor in return is due to the characteristics of urban regeneration areas such as illiquidity, high management costs, lack of property data on profit return and low income flow. A report by DETR (2000[11]) shows investment in regeneration areas often considered as lacking in demand due to factors such as poor location, infrastructure, condition and etc. Regeneration areas characterized as weak in market and low levels of market efficiency. Private investor cautious to invest due to regeneration areas has been accepted as market failure and economic decline (Amin et al, 2000[7]). As a result, it will restrict site development and high land values to allow profit in development. Private investor also perceived regeneration area a confused market signals due to lack of information in their areas itself (McGreal, Webb, Adair and Berry, 2006[20]).

Urban regeneration is to regenerate city of the blighted areas. Thus, the perception of private investor for the blighted areas is poor located and low quality (Adair, Berry, McGreal, 1994[1]). Return on profit gain often related to the economic condition and location factor. Both are importance to stimulate the investment in urban regeneration. A report by Callender and Key (1996[8]) stated that geographic location has a major influence for investment commitment in urban regeneration rather than economic condition. 


\subsection{Governance}

A poor institutional arrangement also highlights as investment constraints in urban regeneration (Adams and Hasting, 2001[6]). This refers to the role of local authority as a policy makers. Bureaucracy and prolong procedure for grant applications and distrust public sector are issues often contribute to the investors cautious to involve in urban regeneration (Adair et al., 1998[2]). Ng (2003[22]) stated that investment in urban regeneration at Sheung Wan, China facing an inadequate funding for land resumption and poor coordination among the government department. Indeed, the role of local authorities is very significant in acquiring, servicing and assembling sufficient land for urban regeneration is required to attract investor in investment. Moreover, providing a clear data for investor may be able to create a certainty condition. Urban regeneration itself is a complex task and it requires resolving the potential conflict in the formation of policies at all level of society. The planning department should consider the wider perspective to reflect the circumstances and requirements of the city or area (Hausner, 1993[16]). The key issue is to understand the entire matters such as local issues, environment and communities in order to succeed in the implementation of urban regeneration investment.

\subsection{Costs and property tax}

Investment in urban regeneration involved a high cost in construction and land assembly. The initial process such as site assembly, demolition, and clearance often through a longer period then bears a high cost in financing charge (Adams et al, .1998[5]). Additionally, it also involves a high cost to destruct business, relocate exist community and high acquisition land (Whipple, 1971[30]). In South Melbourne, for example, property taxes before regeneration were $\$ 1,744$ per annum while after regeneration these arise to $\$ 16,770$ per annum. Increase in property value gives a positive sign to investor, however, extreme increase also will caused the investors fear to invest due to risky as community itself are no longer to live in the area and rundown areas.

\subsection{Destroy neighbourhoods and social network}

Urban regeneration is synonyms with demolishing the entire neighborhoods and destroys the social network (Jacob, 1961[18]). For example, the stalled Plaza Rakyat bus and light rail transit terminal project, and the abandoned of Nas Pavillion upmarket condominium are the examples of urban regeneration which contributed to the decay of the nearby properties in the area. Successful investment in urban regeneration needs to be viewed in a holistic approach. It requires creating lasting improvement in the economic, physical, social and environmental condition of the area that has been subject to change and at the same time all areas and individuals need to be benefit equally rather than been seen as an investment opportunity.

\subsection{Problem of land multiple ownership}

Issue on amalgamation of multiple land ownership also contributes to the investment constraint in urban regeneration (Whipple, 1971[30]). It is because each of the owners in the title will try to being one of the most essential by virtue of size, location and etc. Table 1 below tabulates the summary of categories and determinants of constraints from various literatures. 


\begin{tabular}{|c|c|c|c|c|c|c|c|c|c|c|}
\hline 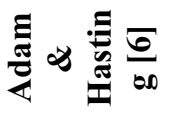 & ๙ิ & & & & & & & & & \\
\hline : & 5 & & & & & & & & & \\
\hline हैं & ह & & & & & & & & & \\
\hline 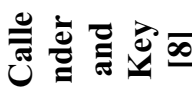 & $\stackrel{2}{2}$ & & & & & & & & & \\
\hline 离 & ğ & & & & & & & & & \\
\hline 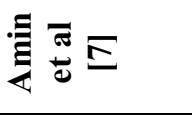 & ڤั & & & & & & & & & \\
\hline 됨 $\simeq$ & ปิ & & & & & & & & & \\
\hline${ }_{Z}^{+0} \bar{\Xi}$ & 气ิ̊ & & & & & & & & & \\
\hline 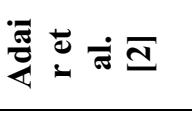 & 2 & & & & & & & & & $>$ \\
\hline 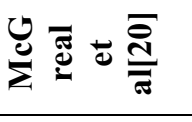 & సั้ & & & & & & & & & $>$ \\
\hline 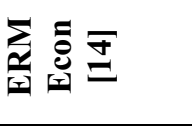 & & & & $>$ & $>$ & & $>$ & & & $>$ \\
\hline 产㐫 $\bar{\Xi}$ & 气ิે & & & & & & & $>$ & $>$ & \\
\hline 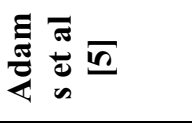 & $\stackrel{2}{2}$ & & & & & & & & & \\
\hline 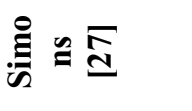 & 2 & & & & & $>$ & & & & \\
\hline 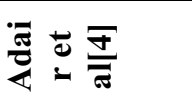 & 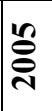 & & $>$ & & & $>$ & & & & $>$ \\
\hline 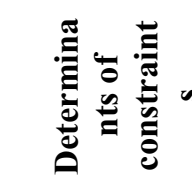 & & 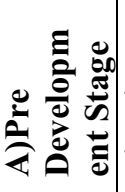 & 总 & 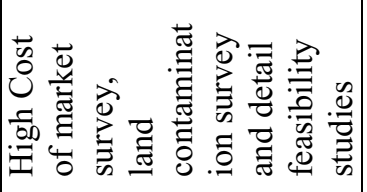 & 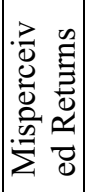 & 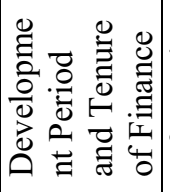 & 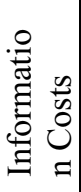 & 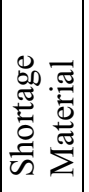 & 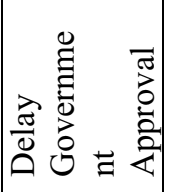 & 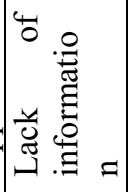 \\
\hline 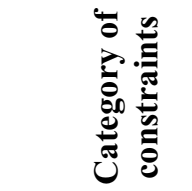 & & $\frac{4}{n}$ & & & & & & & & \\
\hline & & - & & & & & & & & \\
\hline
\end{tabular}




\begin{tabular}{|c|c|c|c|c|c|c|c|c|c|c|c|c|c|}
\hline 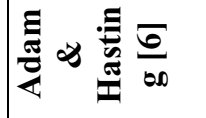 & 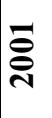 & & & & & & & & & & & & \\
\hline 迅 & 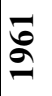 & & & & & & & & & & & & \\
\hline 章吕 & I & & & & & & & & & & & & \\
\hline 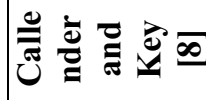 & ळे & & & & & & & & & & & & \\
\hline 严 & aे & & & & & & & & & & & & \\
\hline 㩆元 & 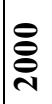 & & & & & & & & & & & & \\
\hline$\overline{\text { 됩 }} \simeq$ & 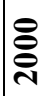 & & & & & & & & & & & & \\
\hline $200 \bar{Z}$ & ڤ్̂ิ & & & & & & & & & & & & \\
\hline 远 & $\stackrel{\infty}{2}$ & & & & & & & & & & & & \\
\hline 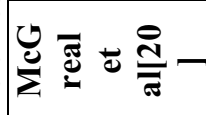 & ¿ั๋ & & & & & $>$ & & & & & & & \\
\hline 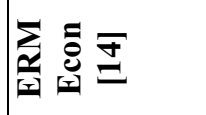 & ָิે & & & & & & $>$ & $>$ & & $>$ & & & $>$ \\
\hline 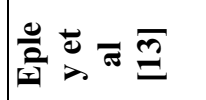 & 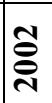 & & & & $>$ & & & & & & $>$ & & \\
\hline 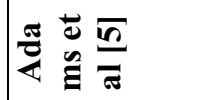 & 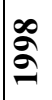 & & & & & & & & & & & & \\
\hline 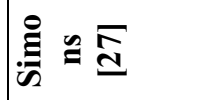 & $\stackrel{2}{2}$ & & $>$ & & & & & & & & & & \\
\hline 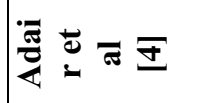 & ֻิ & & \rangle & \rangle & & \rangle & & & & & & \rangle & \\
\hline 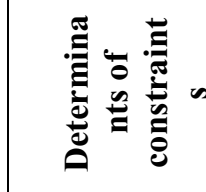 & & 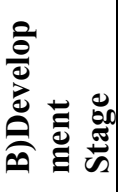 & 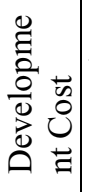 & 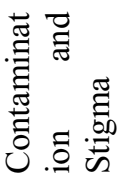 & 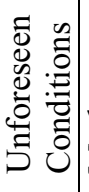 & 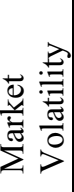 & 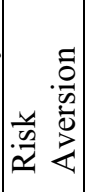 & 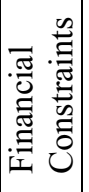 & 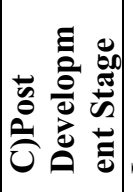 & 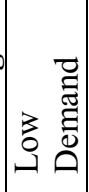 & 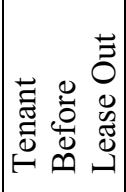 & 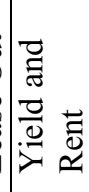 & 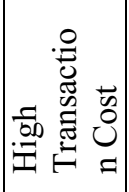 \\
\hline 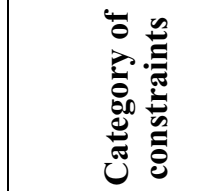 & & & & & & & & & & & & & \\
\hline
\end{tabular}




\begin{tabular}{|c|c|c|c|c|}
\hline 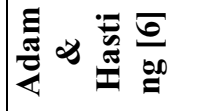 & ฮิ & & & $>$ \\
\hline 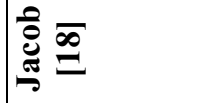 & 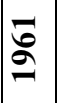 & & & \\
\hline 产气 & 5 & & & \\
\hline 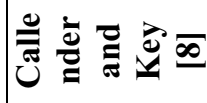 & $\stackrel{2}{2}$ & $>$ & & \\
\hline 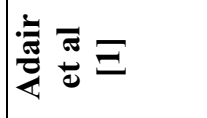 & Бे & $>$ & $>$ & \\
\hline 㩆元 & సิำ & & $>$ & \\
\hline 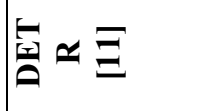 & సิ & $>$ & $>$ & \\
\hline $\bar{Z}^{80} \bar{\Xi}$ & 气ิેి & & & $>$ \\
\hline$\frac{\ddot{\pi}}{2} \pm \dot{\sigma} \Xi$ & $\stackrel{\infty}{2}$ & & & $>$ \\
\hline 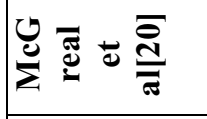 & ڤั้ & & & \\
\hline 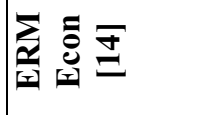 & $\tilde{\overbrace{}}$ & & & \\
\hline 产㐫 & ठิે & & & \\
\hline 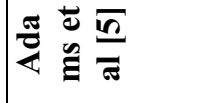 & $\stackrel{2}{2}$ & & & \\
\hline 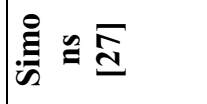 & $\mathscr{2}$ & & & \\
\hline 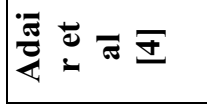 & 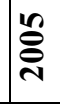 & & & \\
\hline 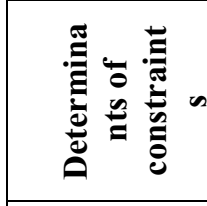 & & 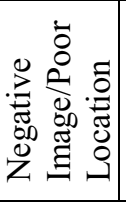 & 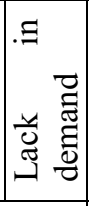 & 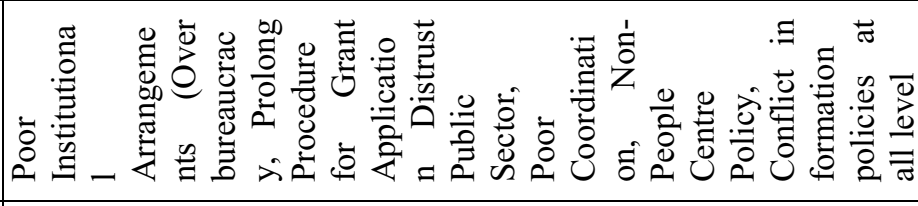 \\
\hline 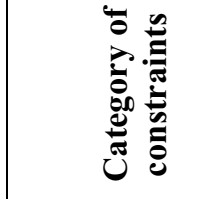 & & 焉 & & 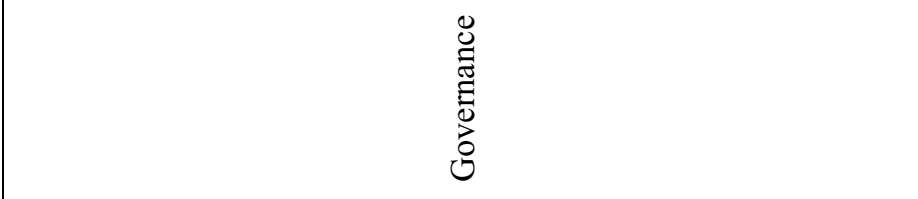 \\
\hline & & $N$ & & $m$ \\
\hline
\end{tabular}




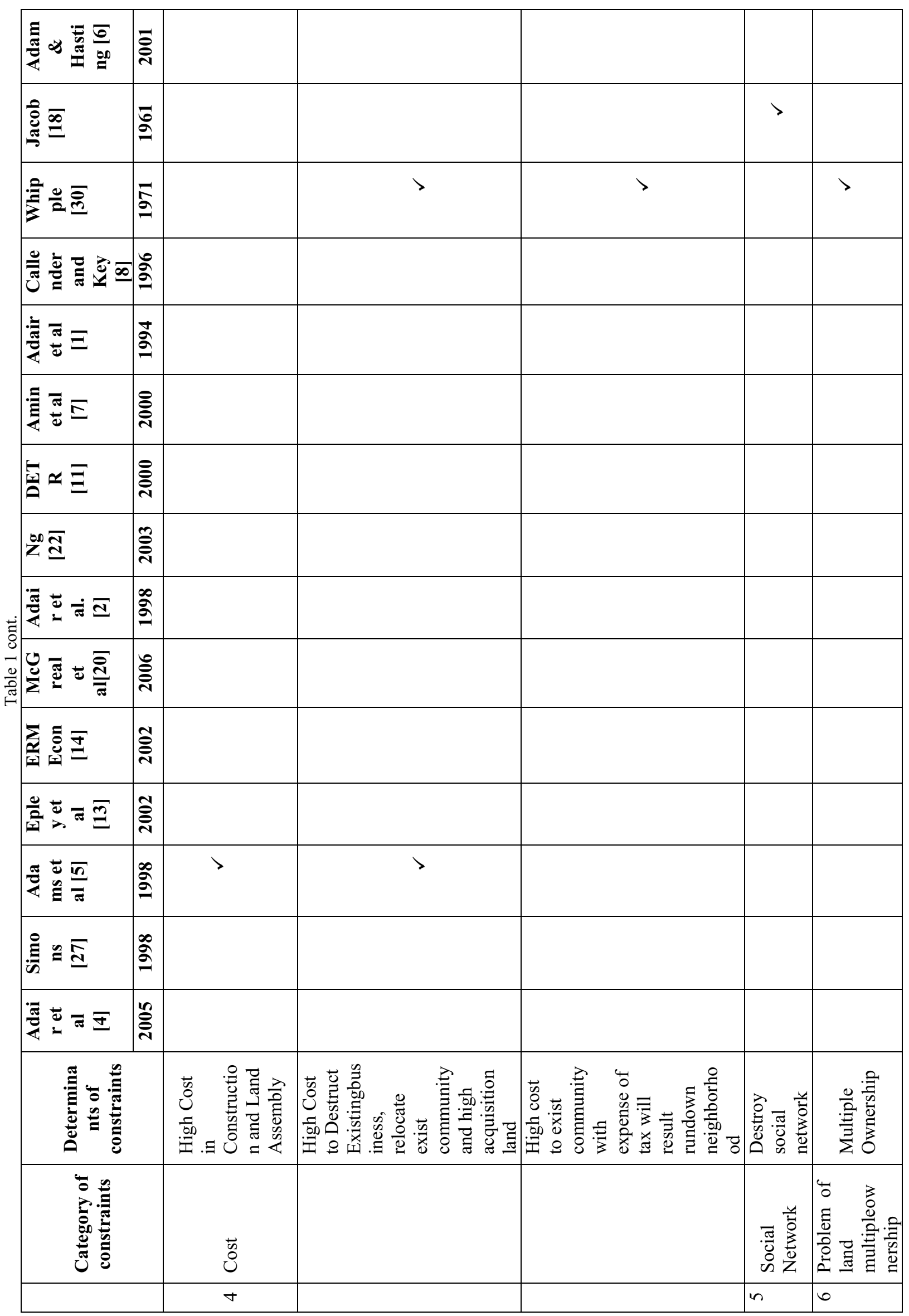


Table 1 illustrates that risk has been considered as the most significant contributor to the constraints of the investment in urban regeneration according to the various literatures. This risk factor can be subdivided into three different phases in the development process namely the pre-development, the development stage and the post development stage. Another significant contributor towards urban regeneration constraint is return. Various literatures agreed that return is one of the motivational factors for both the developers and the local authorities. Cost factor also contributed to the constraints due to these factors is the basis for consideration by investors to pursue their intention to involve in investment of urban regeneration. This is because investment in urban regeneration needs a large amount capital for invested. Therefore, intervention and aid from government is required.

\section{Research methodology}

This study focuses towards the elements of constraints in urban regeneration investment which include six categories namely risks, return, governance, costs and property tax, destroy neighborhood and social network and problem of land multiple ownership. Klang Valley has been chosen as the subject area of the study due to the diversified investments in land and building as well as the renowned developers and well established local authorities. This study has identified 21 established developers and 5 local authorities as the respondents. However, only 11 property developers provide a feedback while all local authorities responded in this study. It involved primary data collection i.e. close ended questionnaire. Data is administered using SPSS software.

\section{Analysis and discussion}

Referring to Table 2 from the property developers perspective reveals that overall land issues on the multiple ownerships (mean score 3.91) is the most significant category that influences developers' constraints. Interestingly, return carries the least mean score of 3.36. This illustrates that return has no correlation with the project type, but it influence by the cost and duration of the project. However, according to each items in Figure 1, it shows that high cost of destruction is the most significant constraints followed by risk in regards to the pre-development, and the issues on multiple land ownerships.
Table 2. The Mean Score of Constraints: Property Developers Perspective

\begin{tabular}{|c|c|c|c|c|}
\hline & $\begin{array}{c}\text { Category of } \\
\text { constraint }\end{array}$ & $\begin{array}{l}\text { Determinants } \\
\text { of constraints }\end{array}$ & $\begin{array}{c}\text { Property } \\
\text { Developers } \\
\text { Mean } \\
\text { Score }\end{array}$ & $\begin{array}{c}\text { Property } \\
\text { Developers } \\
\text { Total Mean } \\
\text { Score }\end{array}$ \\
\hline \multirow[t]{3}{*}{1} & \multirow[t]{3}{*}{ Risk } & $\begin{array}{l}\text { A)Pre } \\
\text { Development } \\
\text { Stage }\end{array}$ & 4.091 & \multirow{3}{*}{3.61} \\
\hline & & $\begin{array}{l}\text { B)Developme } \\
\text { nt Stage }\end{array}$ & 3.455 & \\
\hline & & $\begin{array}{l}\text { C)Post } \\
\text { Development } \\
\text { Stage }\end{array}$ & 3.273 & \\
\hline \multirow[t]{3}{*}{2} & \multirow[t]{3}{*}{ Return } & $\begin{array}{l}\text { Negative } \\
\text { Image/Poor } \\
\text { Location }\end{array}$ & 3.545 & \multirow{3}{*}{3.36} \\
\hline & & $\begin{array}{ll}\text { Poor } & \text { In } \\
\text { Return } & \\
\end{array}$ & 3.364 & \\
\hline & & $\begin{array}{l}\text { Lack in } \\
\text { demand }\end{array}$ & 3.182 & \\
\hline \multirow[t]{2}{*}{3} & \multirow[t]{2}{*}{ Governance } & $\begin{array}{l}\text { Poor } \\
\text { Institutional } \\
\text { Arrangements }\end{array}$ & 3.636 & \multirow[b]{2}{*}{3.55} \\
\hline & & $\begin{array}{l}\text { Conflict in } \\
\text { formation } \\
\text { policies at all } \\
\text { level }\end{array}$ & 3.455 & \\
\hline \multirow[t]{3}{*}{4} & \multirow[t]{3}{*}{ Cost } & $\begin{array}{l}\text { High Cost in } \\
\text { Construction } \\
\text { and Land } \\
\text { Assembly }\end{array}$ & 3.545 & \multirow{3}{*}{3.73} \\
\hline & & $\begin{array}{l}\text { High Cost to } \\
\text { Destruct } \\
\text { Existing } \\
\text { business, } \\
\text { relocate exist } \\
\text { community } \\
\text { and high } \\
\text { acquisition } \\
\text { land }\end{array}$ & 4.091 & \\
\hline & & $\begin{array}{l}\text { High cost to } \\
\text { exist } \\
\text { community }\end{array}$ & 3.545 & \\
\hline 5 & $\begin{array}{c}\text { Social } \\
\text { Network }\end{array}$ & $\begin{array}{l}\text { Destroy } \\
\text { social } \\
\text { network }\end{array}$ & 3.727 & 3.73 \\
\hline 6 & Land Issue & $\begin{array}{l}\text { Multiple } \\
\text { Ownership }\end{array}$ & 3.909 & 3.91 \\
\hline
\end{tabular}




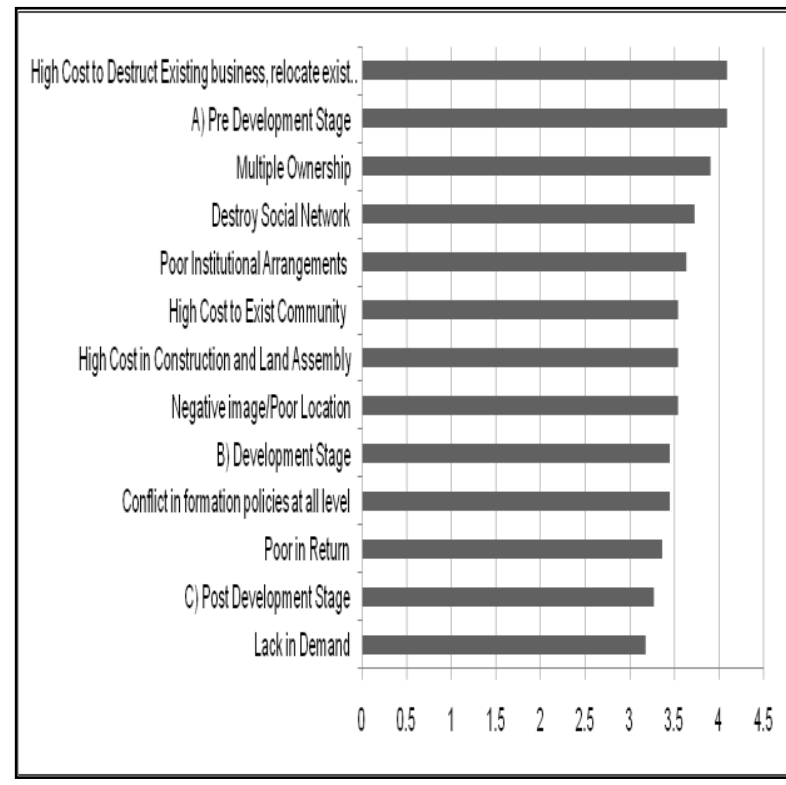

Figure 1. Three Most Significant Constraints: Property Developers Perspective (by ranking)

From the local authority's perspective revealed in Table 3 , overall the most significant category that influence local authorities constraint is the multiple land ownership. This is similar to the perspective of developers. The reason behind this is multiple land ownership is a very challenging and complex issue that can influence the success and failure of the project as it involves dealing with the human behavior. Moreover, it can also drag the project exceeding the stipulated duration and indirectly will increase the project costs. In addition, for the item showed in Figure 2, the significant factors that influence local authority's constraints are multiple ownership issues as well as the high cost of destruction and construction. This is consistent with the developer's constraints as cost is seen as very critical to a project.
Table 3. The Mean Score of Constraints: Local Authorities Perspective

\begin{tabular}{|c|c|c|c|c|}
\hline & $\begin{array}{l}\text { Category of } \\
\text { constraint }\end{array}$ & $\begin{array}{l}\text { Determinants } \\
\text { of constraints }\end{array}$ & $\begin{array}{l}\text { Local } \\
\text { Authorities } \\
\text { Mean Score }\end{array}$ & $\begin{array}{c}\text { Local } \\
\text { Authoriti } \\
\text { es Total } \\
\text { Mean } \\
\text { Score }\end{array}$ \\
\hline \multirow[t]{3}{*}{1} & \multirow[t]{3}{*}{ Risk } & $\begin{array}{l}\text { A)Pre } \\
\text { Development } \\
\text { Stage }\end{array}$ & 3.800 & \multirow{3}{*}{3.27} \\
\hline & & $\begin{array}{l}\text { B)Developme } \\
\text { nt Stage }\end{array}$ & 3.400 & \\
\hline & & $\begin{array}{l}\text { C)Post } \\
\text { Development } \\
\text { Stage }\end{array}$ & 2.600 & \\
\hline \multirow[t]{3}{*}{2} & \multirow[t]{3}{*}{ Return } & $\begin{array}{l}\text { Negative } \\
\text { Image/Poor } \\
\text { Location }\end{array}$ & 3.400 & \multirow{3}{*}{3.33} \\
\hline & & Poor In Return & 3.200 & \\
\hline & & $\begin{array}{ll}\text { Lack } \\
\text { demand }\end{array}$ & 3.400 & \\
\hline \multirow[t]{2}{*}{3} & \multirow[t]{2}{*}{ Governance } & $\begin{array}{l}\text { Poor } \\
\text { Institutional } \\
\text { Arrangements }\end{array}$ & 3.800 & \multirow[b]{2}{*}{3.80} \\
\hline & & $\begin{array}{l}\text { Conflict in } \\
\text { formation } \\
\text { policies at all } \\
\text { level }\end{array}$ & 3.800 & \\
\hline \multirow[t]{3}{*}{4} & \multirow[t]{3}{*}{ Cost } & $\begin{array}{l}\text { High Cost in } \\
\text { Construction } \\
\text { and Land } \\
\text { Assembly }\end{array}$ & 4.000 & \multirow{3}{*}{3.93} \\
\hline & & $\begin{array}{l}\text { High Cost to } \\
\text { Destruct } \\
\text { Existing } \\
\text { business, } \\
\text { relocate exist } \\
\text { community } \\
\text { and high } \\
\text { acquisition } \\
\text { land }\end{array}$ & 4.000 & \\
\hline & & $\begin{array}{l}\text { High cost to } \\
\text { exist } \\
\text { community }\end{array}$ & 3.800 & \\
\hline 5 & $\begin{array}{c}\text { Social } \\
\text { Network }\end{array}$ & $\begin{array}{l}\text { Destroy social } \\
\text { network }\end{array}$ & 3.600 & 3.60 \\
\hline 6 & Land Issue & $\begin{array}{l}\text { Multiple } \\
\text { Ownership }\end{array}$ & 4.000 & 4.00 \\
\hline
\end{tabular}




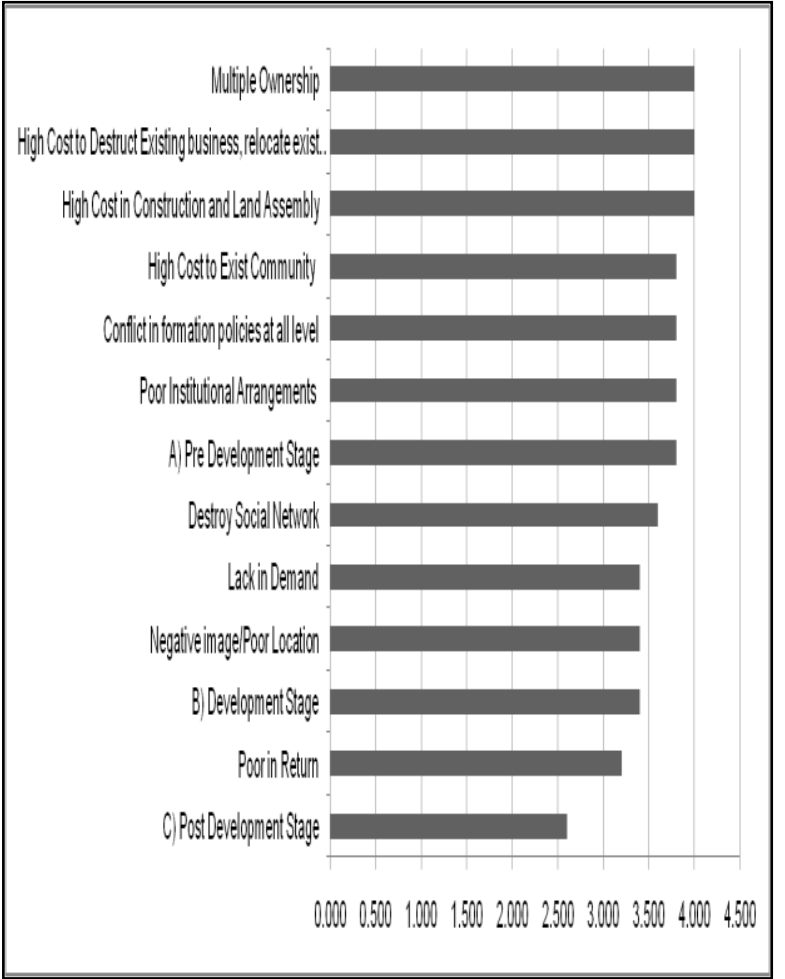

Figure 2. Three Most Significant Constraints: Local Authorities Perspective (by ranking)

There are a few gaps between both the developers and local authorities' perspective. These differences are influence by the objectives and direction of the organization, and the setting up of the organization. Figure 3 illustrates the radar chart between these two perspectives. The most significant gaps are in regards risk to the post development stage, followed by the high cost in construction and land assembly and lastly conflict in formation policies at all level. It should be noted that both developers and the local authorities are two different entities with different objectives. Hence this can explain the lower mean score from the local authorities' perspective as the developers are profit oriented organization while the local authorities are concern more towards the welfare of the society. The post development stage can only be estimated or projected as this will only happen after the project is finished and there are elements of uncertainty and risk. This will concern more to the local authorities as it has a strong relationship with the well being of the society in that particular areas. The developers on the other hand, once the development has been handover - this means the project is finish and they have no further interest towards it.

The second gap is on the high cost in construction and land assembly. For a profit oriented organization this will definitely affect the bottom line of the profit and loss accounts. Thus, cost is a critical factor and need to be managed effectively and efficiently. Cost in the local authority perspectives is whether or not the allocation is adequate to finance the project. This is due to the fact that the local authority's administration system is consists of different level of administration thus making decision is time consuming and involve lengthy process and procedures.
The third gap is on the conflict in the formation policies which concern more to the local authorities compared to the developers. This is due to the fact that the local authorities consist of different departments, different level of decision making - hence, decision making becomes complex and time consuming involving bureaucracy etc. For developers this is a simple process involving the board of directors only.

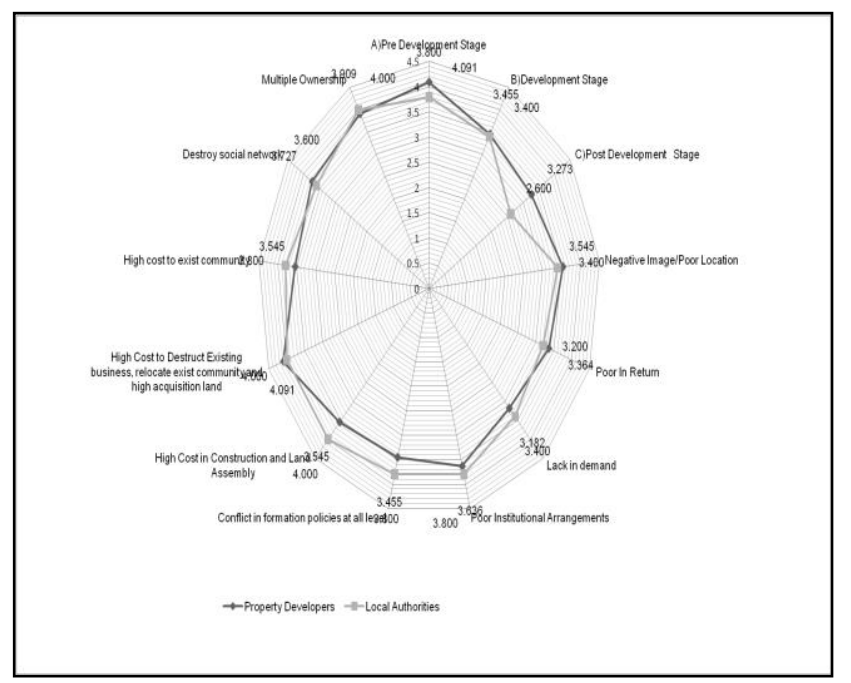

Figure 3. Radar Chart on Constraints: Property Developers and Local Authorities Perspective

\section{Conclusion}

The developers and local authorities are the key players in the built environment and their motivation towards urban regeneration investment is consider highly importance towards achieving sustainable and resilience, urban living and environment. Hence, although both have different perspectives towards this investment but this does not mean that it cannot be materialize. The challenge now is to come out with more incentives and strategies that can boost the motivations of both parties to collaborate in this investment. Urban regeneration is a key growth of economic, social and physical of a country and studies and experiences from other countries have showed that investment in urban regeneration can be as successful as any other investments. Moreover, the benefits gains are very valuable and significance particularly to the urban decay area as well as the whole nation. Despite the challenges face by the key players in the built environment, urban regeneration investment should be a priority to develop the nation to achieve an inclusive, resilience, safe and livable cities. 


\section{References}

1. Adair A.S., Berry, J.N., and McGreal W.S. (1994). Investment Decision Making: A Behavioral Perspective, Journal of Property Finance. Vol. 5(4). pp. 32-42

2. Adair, A.S., Berry, J.N., Deddies, W.G., McGreal, W.S., and Hirst, S.M. (1998). Accessing Private Sector Finance. Royal Institution of Chartered Surveyors, London. pp 51.

3. Adair, A.S., Berry, J.N., McGreal, W.S., and Quinn, A. (2003). Factors Affecting The Level and Form of Private Investment in Regeneration, Urban Research Summary Number 6, Office of the Deputy Prime Minister. pp7.

4. Adair. A., Berry. J., McGreal. S., Poon. J., Hutchison. N., Watkins. C., and Gibb. K. (2005). Investment Performance within Urban Regeneration Location, Journal of Property Investment and Finance. Vol. 23(1). pp.7-21.

5. Adams, D., Disberry, A., Hutchison, N., and Munjoma, T. (1998). Do landowners constrain urban redevelopment?. Aberdeen Papers in Land Economy: Discussion Paper, University of Aberdeen, Aberdeen. pp 99-01.

6. Adams, D., and Hastings, E.M. (2001). Assessing Institutional Relations in Development Partnerships: The Land Development Corporation and The Hong Kong Government Prior to 1997, Urban Studies. Vol. 38(.9), pp. 1473-92.

7. Amin, A., Massey, D., and Thrft, N. (2000). Cities for the Many, not the Few, Bristol. The Policy Press. pp 48.

8. Callender, M. and Key, T. (1996). The Total Value of Commercial Property in the UK. Paper presented at the Royal Institution of Chartered Surveyors Cutting Edge Conference, University of the West of England, Bristol.

9. Couch, C. (1990). Urban Renewal Theory and Practice. MacMillan, Basingtoke.

10. Cox. K., Viruly. F., Bertoldi. A., (2015). Inner City Transformation \& Investment Trends (2009-2014). Johannesburg Development Agency.

11. DETR (Department of The Environment, Transport and The Regions) (2000). Our Towns and Cities: The Future. The Urban White Paper. The Stationery Office, London.

12. Eni, Sabariah, Adair. A., Cheng. L., and Lim. J. (2013). Financing Urban Redevelopment in Kuala Lumpur, Malaysia: Prospects and Challenges. Paper presented in 20th Annual European Real Estate Society Conference. ERES: Conference. Vienna, Austria.

13. Epley. D.R., Rabianski. J.S., Haney. R.L. (2002), Real Estate Decisions. South-Western Thomson Learning.
14. ERM Economics (2002). Evaluating the Impact of Urban White Paper Fiscal Measures. Report to the DTLR (Department of Transport, Local Authorities and the Regions), London.

15. Goksin and Muderrisoglu (2005). Urban Regeneration: A Comprehensive Strategy. $41^{\text {st }}$ Isocarp Congress, Istanbul.

16. Hausner, V.A (1993). The Future of Urban Development. Royal Societies of Arts Journal. Vol. 141, pp. 523-33.

17. IOER (May 2005). Compendium: Handbook 3 Sustainable Urban Regeneration and Its Assessment. LUDA Project.

18. Jacob (1961). The Death and Life of Great American Cities. Vinateg, New York.

19. Malaysia Statistics Department (2015). Population Data. Retrieved from https://www.statistics.gov.my.

20. McGreal. S., Webb. J.R., Adair. A., Berry. J. (2006). Risk and Diversification for Regeneration/Urban Renewal Properties: Evidence from the U.K. Journal of Real Estate Portfolio Management. Vol 12 (1).pp $1-12$.

21. McNamara, P. (1993). Parameters for Institutional Investment in Inner City Commercial Property Markets, in Berry, J. McGreal, S. and Deddies, W. (Eds), Urban Regeneration, E. \& F.N. Spon, London. pp.5-15.

22. Ng, I., (2003). Community Approach: is a Solution to Age-Old Problem of Urban Renewal in Hong Kong, International Journal for Housing Science. Vol. 27 (1). pp. 75-88.

23. Nilai Harta (2015). Urban Regeneration in Malaysia: Issues and Practices, Malaysia Retrieved from http://www.nilaiharta.com.my/articles

24. Peter W. Robert and Hugh Skyes (2000). Urban Regeneration A Handbook. SAGE Publication Ltd, London.

25. Planning in Association with Regeneration and Renewal (2013). The Top 100 Regeneration Projects 2013. London. pp 1-13.

26. Samworth, M. and Lacey, C. (1998). Remove guesswork from spec work. Estate Gazette, No. 9842, pp. 160-1.

27. Simons, R.A. (1998). Turning Brownfields into Greenbacks. Urban Land Institute. Washington, DC.I

28. The Edge TV (2014). Malaysia's Urbanisation Rate Expected to Rise To 75\% in 2020 [Youtube Video]. The Edge Malaysia (City \& Country).

29. Warner. L., and Long. E. (2009). Executive Summary Impact Analysis of Oklahoma City's Maps And Other Significant Central City Investments. Greater Oklahoma City Chamber of Commerce.

30. Whipple. R.T.M. (1971). Urban Renewal and the Private Investor. West Publishing Corporation Pty Ltd, Sydney. 